\title{
PARAOXONASE ACTIVITY IN LIVER OF PACU, PIARACTUS MESOPOTAMICUS HOLMBERG (CHARACIDAE)
}

\author{
Vera Lucia F. Cunha Bastos ${ }^{1}$ \\ Evelize Folly ${ }^{1}$ \\ Ana Rossini ${ }^{1}$ \\ Paulo S. Ceccarelli ${ }^{2}$ \\ José A. Senhorini ${ }^{2}$ \\ Jayme Cunha Bastos ${ }^{1}$
}

\begin{abstract}
Enzymatic production of p-nitrophenol in liver of Piaractus mesopotamicus Holmberg, 1887 was consistently assayed at $\mathrm{pH} 8.5$ using $7.5 \mathrm{mM}$ paraoxon as substrate. This pacu liver paraoxonase activity was activated by $\mathrm{NaCl}$. Apparent values of $\mathrm{K}_{\mathrm{M}}$ were $2.42 \times 10^{-3} \mathrm{M}$ in the presence of $0.5 \mathrm{M} \mathrm{NaCl}$ and $8.99 \times 10^{-3} \mathrm{M}$ without $\mathrm{NaCl}$. Apparent maximum velocity values calculated in the absence and presence of $0.5 \mathrm{M} \mathrm{NaCl}$ were $1.09 \times 10^{-3} \mu \mathrm{moles} / \mathrm{min} / \mathrm{mg}$ of proteins and $1.29 \times 10^{-3} \mu \mathrm{mo}$ les/min/mg of proteins, respectively. These $V_{\max }$ values are fifty-fold the value described for trout (Salmo trutta Linnaeus, 1758) liver paraoxonase. Paraoxonase activity of pacu liver homogenates was recovered as much in cytosolic as in particulate cellular subfractions, but the particulate subfractions showed higher specific activities. The data presented here indicate that hepatic hydrolysis of organophosphorous pesticides may not be an important detoxification process in pacu.

KEY WORDS. Detoxication, esterase, fish, organophosphate
\end{abstract}

As a result of crop defensive practices aquatic animals may absorb pesticides from contaminated water drained off into rivers from surrounding farmland. Absorbed pesticides may harm fish. On the other hand, organophosphorous insecticides have been used to protect fish against parasites in fish-farming tanks (GRAVE et al. $1991 \mathrm{a}, \mathrm{b})$. Therefore there is a need to learn steadily more about fish toxicant metabolism.

Organophosphorous insecticides are toxic because they inhibit nerve synaptic acetylcholinesterase. Many organophosphorous substances have a phosphorothionate structure ( $\mathrm{P}=\mathrm{S}$ group) that cannot efficiently bind to cholinesterase: they must be bioactivated to produce the corresponding phosphate ( $\mathrm{P}=\mathrm{O}$ group) that is able to inhibit acetylcholinesterase by binding to the esterasic site of the enzyme. Several authors have referred to metabolization of xenobiotics by fish liver (PEDERSEN et al. 1976; BURNS 1976; HINTON et al. 1978, 1985; NOWAK 1996). In fact, the

1) Departamento de Bioquímica, Instituto de Biologia Roberto Alcântara Gomes, Universidade Estadual do Rio de Janeiro. Avenida Prof. Manuel de Abreu 48, 20550-170 Rio de Janeiro, Rio de Janeiro, Brasil.

2) Centro Nacional de Pesquisas em Peixes Tropicais. Caixa Postal 64, 13630-970 Pirassununga, São Paulo, Brasil.

Revta bras. Zool. 15 (5): 677 - 685, 1998 
liver is the major organ involved in the organophosphorous bioactivation process (Sultatos et al. 1985). Measuring acetylcholinesterase inhibition in vitro, we showed that parathion (O,O-diethyl, O-p-nitrophenyl phosphorothionate) is activated to paraoxon (O,O-diethyl, O-p-nitrophenyl phosphate) through a monooxigenase system existing in liver of Hypostomus punctatus Valenciennes, 1840, a Brazilian suckermouth catfish (CUNHA BASTOS et al. 1992). Liver homogenates of pacu, Piaractus mesopotamicus Holmberg, 1887 , also showed the ability to produce inhibition of acetylcholinesterase during incubation with parathion in vitro (not published data from our laboratory).

As described in rat, before reaching the brain, where it causes toxic acetylcholinesterase inhibition, paraoxon produced from parathion in the liver undergoes several detoxicating chemical interactions (NEAL \& DUBOIS 1965; PLA \& JOHNSON 1989; POND et al. 1995). Among them, paraoxonase activity renders paraoxon ineffective by splitting it into p-nitrophenol and diethyl-phosphate (GAINES et al. 1966; NEAL 1967). Thus, high levels of paraoxonase are considered protective against poisoning caused by active metabolites of organophosphorous pesticides (GELDMACHER-VON MALLINCKRODT \& DIEBGEN 1988; LI et al. 1995). In spite of what has already been published on mammals paraoxonase activity, we still have scarce biochemical information about any fish liver detoxicating esterase activities. In view of these facts, we felt the need to determine the enzymatic capability that liver of $P$. mesopotamicus could have of hydrolyzing paraoxon. The extent of such a reaction would allow the assessment of the efficiency with which liver of pacu minimizes the effect of organophosphate intoxication on the nerve system.

This paper describes procedures to establish the main optimal assay parameters of paraoxonase activity we found in $P$. mesopotamicus liver. Biochemical kinetic constants were calculated as long as their values give a good approximation regarding the magnitude of paraoxon hydrolysis in pacu liver. To better characterize the paraoxon esterase activity in pacu liver we studied how this activity is affected by $\mathrm{NaCl}, \mathrm{CaCl}_{2}$ and EDTA. Distribution of paraoxonase activity among liver cellular subfractions obtained trough differential centrifugation was investigated as an attempt to verify whether this activity could be typical of some intracellular organelle.

\section{MATERIAL AND METHODS}

\section{Reagents}

Trichloroacetic acid (TCA), Trizma $($ (2-amino-2-[hydroxymethyl-1,3-propanediol]), hydrochloric acid $(\mathrm{HCl})$, paraoxon $(\mathrm{O}, \mathrm{O}$-diethyl $\mathrm{O}$-p-nitrophenyl phosphate), EDTA (ethylenediamine tetracetic acid disodium salt) and dimethyl sulfoxide (DMSO) were purchased from Sigma Chemical Company, St. Louis, MO, U.S.A. Hexane specific for pesticide analysis was purchased from Grupo Química Industrial Ltda., Rio de Janeiro, Brazil. All other chemicals were of analytical grade.

\section{Fish}

Specimens of Piaractus mesopotamicus (pacu) were obtained from the National Centre for Research on Tropical Fish (CEPTA) of the Brazilian Environment and Renewable Natural Resources Institute (IBAMA). Sexually mature 
pacus measured around $23 \mathrm{~cm}$ from snout to tail and weighed approximately 150 g. The animals were kept in $500 \mathrm{~L}$ aerated tanks at room temperature. The tanks contained dechlorinated water and were equipped with biologic filter. All fish were acclimated for at least 10 days before being used. Fish were fed on the appropriate pellets produced in CEPTA and were exposed to normal light-dark day cycles.

\section{Preparation of cellular subfractions}

Fish were sacrificed by decapitation and their livers were removed, weighed, minced and homogenized in four volumes of cold $0.1 \mathrm{M}$ potassium phosphate buffer, $\mathrm{pH} 7.0$, containing $0.25 \mathrm{M}$ sucrose. The homogenate was fractionated by centrifugation under refrigeration at $15,000 \mathrm{xg}$ for $30 \mathrm{~min}$ in order to separate intact cells and nuclei. The nuclear pellet (P1) was set apart and the supernatant (S1) was centrifuged at $105,000 \mathrm{xg}$ for $90 \mathrm{~min}$. The second supernatant (S2) was decanted and set apart. The deposited microsomal fraction (P2) was washed once and suspended in the potassium phosphate buffer. Each subfraction was taken for protein and enzymatic activity determinations. Protein was determined by the modified (FARIA \& BRASIL 1959) Greenberg method (GREENBERG 1929).

\section{Paraoxonase activity assay}

The ordinary paraoxonase assay consisted in measuring the p-nitrophenol resulting from paraoxon hydrolysis at $\mathrm{pH} 8.5$ and $30^{\circ} \mathrm{C}$. In order to clean up paraoxon removing the contaminating p-nitrophenol, a small volume of paraoxon was mixed with 8 volumes of sodium phosphate buffer $0.1 \mathrm{M}, \mathrm{pH} 7.4$, and 8 volumes of hexane in an assay tube. This content was vigorously shaken to ensure paraoxon solubilization. After phase separation, the superior layer was transferred to a brownish-glass flask and nitrogen was bubbled inside this flask till hexane had evaporated. The residue was used as paraoxonase substrate. This simple procedure proved to be extremely useful to assure low blank absorbance values. Substrate was prepared as a $45 \mathrm{mM}$ paraoxon solution made by mixing $20 \mathrm{mg}$ of the repurified paraoxon with $726 \mu \mathrm{L}$ of DMSO and $888 \mu \mathrm{L}$ of $0.1 \mathrm{M}$ Tris- $\mathrm{HCl}$ buffer, $\mathrm{pH} 8.5$ (substrate solution). The assay contained a volume of sample corresponding to the required protein amount and $0.1 \mathrm{M}$ Tris- $\mathrm{HCl}$ buffer solution, $\mathrm{pH} 8.5$, to reach a final incubation volume of $300 \mu \mathrm{L}$. A $50 \mu \mathrm{L}$ volume of the substrate solution were pipetted to start the enzymatic reaction. When salts were needed in the assays this substrate Tris- $\mathrm{HCl}$ buffered paraoxon solution also contained $3 \mathrm{M} \mathrm{NaCl}$ and $12 \mathrm{mM} \mathrm{CaCl}_{2}$. Enzyme activity at different $\mathrm{pH}$ values and the velocity versus substrate concentration curves were performed as already described (CUNHA BASTOS et al. 1998). Different paraoxon concentrations were used in the range of 0.015 to $7.5 \mathrm{mM}$ to perform $\mathrm{v} x$ [S] curves, in a constant concentration of DMSO (7.5\%). To stop the reaction 0.9 $\mathrm{mL}$ of a $3 \% \mathrm{TCA}$ (in water) were pipetted into the tubes at the end of each incubation time. In the blanks, a volume of $50 \mu \mathrm{L}$ of the substrate solution was pipetted into the tubes (using solution which had been left along the entire reaction time under the incubation temperature) just after TCA addition. Then, the tubes were centrifuged at $4,000 \mathrm{rpm}$ for $15 \mathrm{~min}$ and $0.9 \mathrm{~mL}$ aliquots of each supernatant were mixed with $0.2 \mathrm{~mL}$ of a $0.3 \mathrm{M}$ Tris- $\mathrm{HCl}$ buffer solution, $\mathrm{pH}$ 8.0. Absorbance measurement in each tube was registered at $400 \mathrm{~nm}$ using a Shimadzu UV-160A spectrophoto- 
meter in $1 \mathrm{~cm}$ optical path cuvettes. A p-nitrophenol standard curve (1.5 to $75 \mathrm{nmoles}$ concentration range) was used for calculation of the amount of p-nitrophenol. Statistical calculations were performed using Student's unpaired $t$ test. One unit of enzyme activity corresponded to $1 \mu \mathrm{mol}$ of $\mathrm{p}$-nitrophenol produced within one minute of reaction.

\section{RESULTS}

As it can be seen in figures 1 and 2 the velocity of paraoxonase reaction in pacu liver homogenates shows a linear progress within the time intervals and protein concentrations chosen. Less than $7 \%$ of the $7.5 \mathrm{mM}$ added paraoxon was utilized over the $20 \mathrm{~min}$ assay time by $1 \mathrm{mg}$ of liver homogenate proteins.
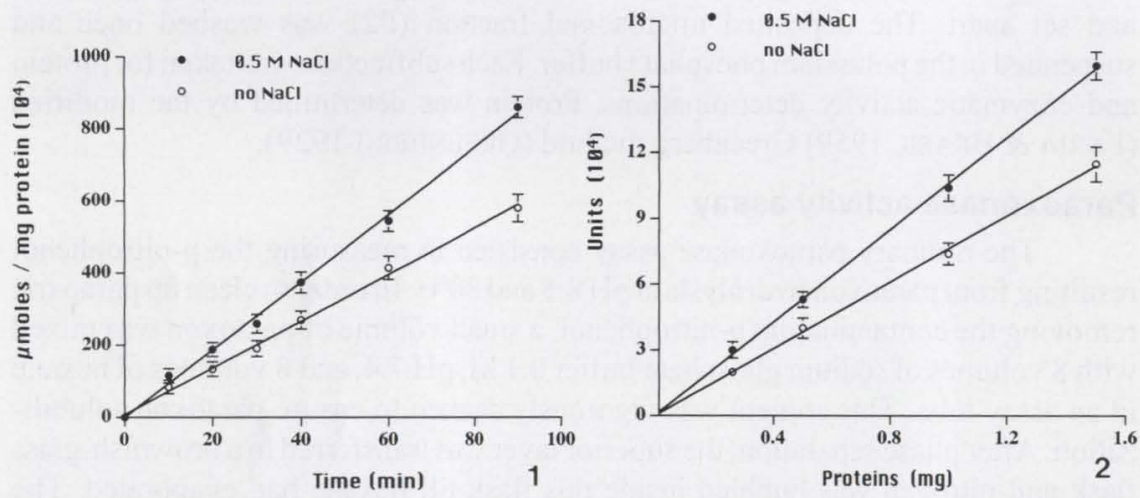

Figs 1-2. Paraoxonase liver activity. (1) As a function of incubation time and (2) as a function of protein (enzyme) amounts. Assays were performed at $30^{\circ} \mathrm{C}$ using $0.1 \mathrm{M}$ Tris- $\mathrm{HCl}$ buffer solution, $\mathrm{pH} 8.5,0.5 \mathrm{M} \mathrm{NaCl}, 2 \mathrm{mM} \mathrm{CaCl}_{2}, 1 \mathrm{mg}$ of protein in each tube (only figure 1) and 7.5 $\mathrm{mM}$ paraoxon. Each point is the mean of five assays \pm S.E.M.

The velocity curve versus $\mathrm{pH}$ of the incubation medium shows that the best $\mathrm{pH}$ to assay pacu liver paraoxonase activity was 8.5 (Fig. 3). Activities stimulated by $0.5 \mathrm{M} \mathrm{NaCl}$ were higher from $\mathrm{pH} 7.0$ to 8.0 when compared to activities assayed without $\mathrm{NaCl}$.

In figures 4 and 5 it is seen that both, $\mathrm{NaCl}$ and $\mathrm{CaCl}_{2}$, activate liver paraoxonase activity. Adding sodium to the incubation medium increases paraoxonase activity around $25 \%$ to $43 \%$. Concentrations between $0.5 \mathrm{M}$ and $2.0 \mathrm{M} \mathrm{NaCl}$ produce a significant $(\mathrm{p}<0.05)$ activation (Fig. 4). Calcium activates paraoxonase liver activity nearly two-fold. Significantly similar levels of activation are observed between $1 \mathrm{mM}$ and $10 \mathrm{mM} \mathrm{CaCl}_{2}$ (Fig. 5). EDTA is effective in inhibiting the paraoxonase activity of liver of pacu. It can be seen in figure 6 that activity is reduced to $25 \%$ in the presence of $0.25 \mathrm{mM}$ EDTA.

Figures $7 \mathrm{~A}$ and $\mathrm{B}$ clearly show that $0.5 \mathrm{M} \mathrm{NaCl}$ provokes a decrease in the affinity of liver paraoxonase for paraoxon. The apparent $\mathrm{K}_{\mathrm{M}}$ value without $\mathrm{NaCl}$ in the assays $(8.99 \mathrm{mM})$ is at least three-fold the apparent $\mathrm{K}_{\mathrm{M}}$ calculated in the presence 
of $0.5 \mathrm{M} \mathrm{NaCl}(2.42 \mathrm{mM})$. Accordingly, the $\mathrm{V}_{\max } / \mathrm{K}_{\mathrm{M}}$ ratio values in the presence and absence of $0.5 \mathrm{M} \mathrm{NaCl}$ are $4.9 \times 10^{-4}$ and $1.2 \times 10^{-4} \mathrm{~min}^{-1} \mathrm{xg}^{-1} \times \mathrm{L}$, respectively.
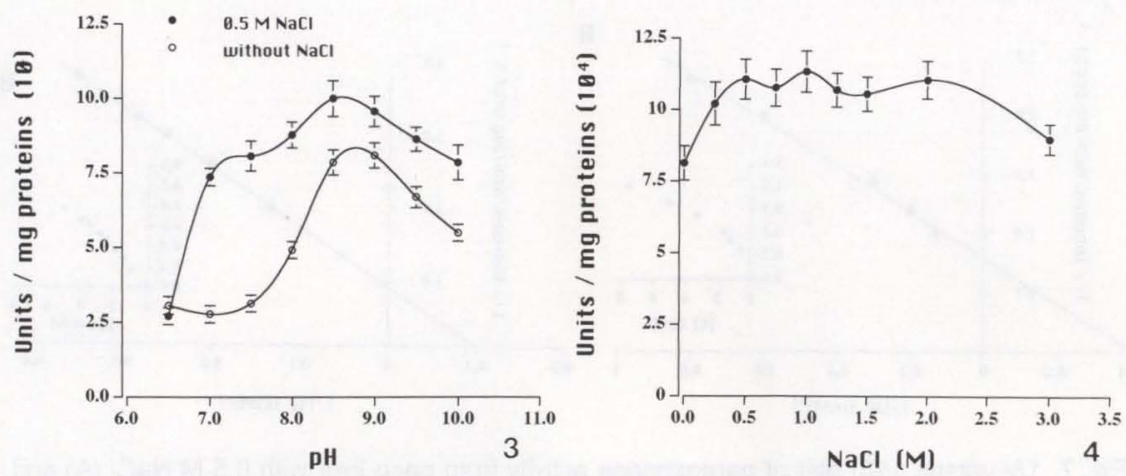

Figs 3-4. (3) Influence of $\mathrm{pH}$ on paraoxonase liver activity. Assays were performed at $30^{\circ} \mathrm{C}$ for 20 min using $1 \mathrm{mg}$ of protein in each tube, $0.5 \mathrm{M} \mathrm{NaCl}, 2 \mathrm{mM} \mathrm{CaCl}_{2}$ and $7.5 \mathrm{mM}$ paraoxon. The buffers used were $0.1 \mathrm{M}$ Sodium Phosphate for $\mathrm{pH} 6.5,0.1 \mathrm{M}$ Tris- $\mathrm{HCl}$ for $\mathrm{pH}$ values from 7.0 to 9.0 and $0.1 \mathrm{M}$ glycine- $\mathrm{NaOH}$ for $\mathrm{pH} 9.5$ and $\mathrm{pH} 10.0$. Each point is the mean of five assays \pm S.E.M.. (4) effect of $\mathrm{NaCl}$ concentration on paraoxonase activity of pacu liver. Assays were performed at $30^{\circ} \mathrm{C}$ for $20 \mathrm{~min}$, using $0.1 \mathrm{M}$ Tris- $\mathrm{HCl}$ buffer solution, $\mathrm{pH} 8.5,1 \mathrm{mg}$ of protein, $2 \mathrm{mM} \mathrm{CaCl}_{2}$ and $7.5 \mathrm{mM}$ paraoxon. Different volumes of a $3 \mathrm{M} \mathrm{NaCl}$ solution were used to obtain the plotted $\mathrm{NaCl}$ concentrations. Each point is the mean of five assays \pm S.E.M.
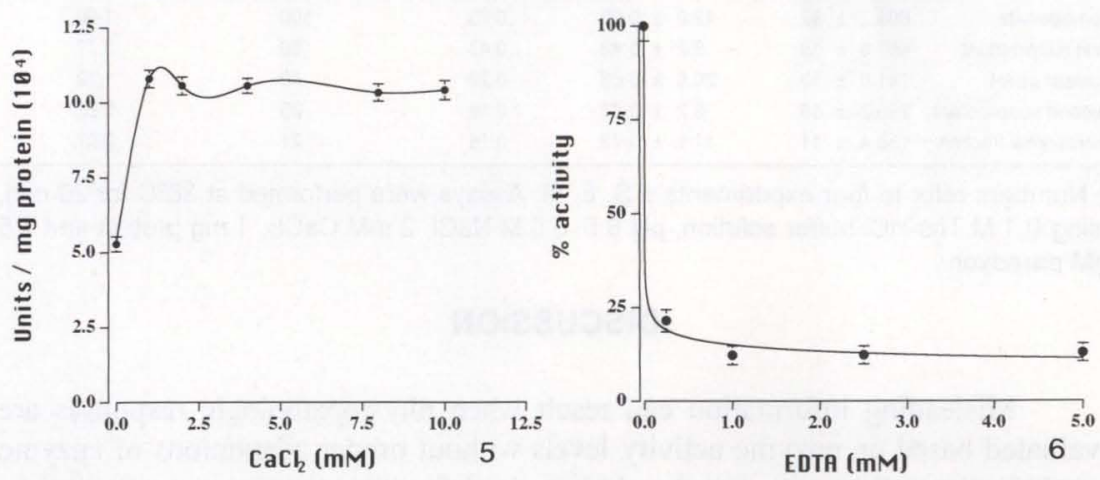

Figs 5-6. Effect of $\mathrm{CaCl}_{2}$ (5) and EDTA (6) concentration on paraoxonase activity of pacu liver. (5) Assays were performed at $30^{\circ} \mathrm{C}$ for $20 \mathrm{~min}$, using $0.1 \mathrm{M}$ Tris- $\mathrm{HCl}$ buffer solution, $\mathrm{pH} 8.5,1$ $\mathrm{mg}$ of protein, $0.5 \mathrm{M} \mathrm{NaCl}$ and $7.5 \mathrm{mM}$ paraoxon. Different volumes of a $12 \mathrm{mM} \mathrm{CaCl}_{2}$ solution were used to obtain the plotted $\mathrm{NaCl}$ concentrations. Each point is the mean of 5 assays \pm S.E.M. (6) Assays were performed at $30^{\circ} \mathrm{C}$ with or without $0.5 \mathrm{M} \mathrm{NaCl}$ and $2 \mathrm{mM} \mathrm{CaCl}_{2}$, using $1 \mathrm{mg}$ of protein, $0.1 \mathrm{M}$ Tris- $\mathrm{HCl}$ buffer solution, $\mathrm{pH} 8.5$, and $7.5 \mathrm{mM}$ paraoxon.

Table I shows that nearly $60 \%$ of the pacu liver paraoxonase activity occurs in the citoplasmatic cellular subfraction S1. The microsomal pellet contained about half of the activity recovered after ultracentrifuging S1 at $105,000 \mathrm{x}$ g. Considering 
the low amount of protein in pellets $\mathrm{P} 1$ and $\mathrm{P} 2$ when compared to the protein amount present in S1 and S2 it can be observed that the pellets fractions are the richest in paraoxonase activity.
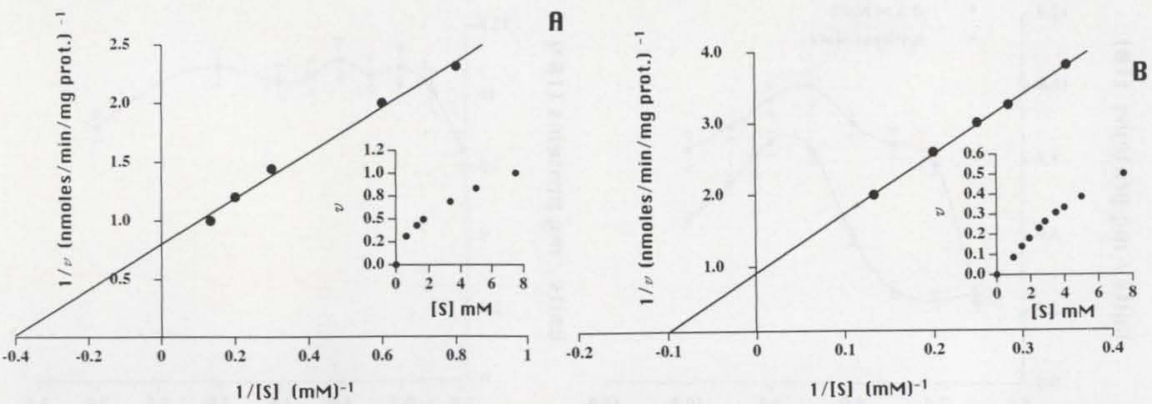

Fig. 7. $1 / \mathrm{v}$ versus $1 /[\mathrm{S}]$ plot of paraoxonase activity from pacu liver with $0.5 \mathrm{M} \mathrm{NaCl}(A)$ and without $\mathrm{NaCl}(\mathrm{B})$. The inserted graphics show the corresponding $v$ versus $[\mathrm{S}]$ curves. Assays

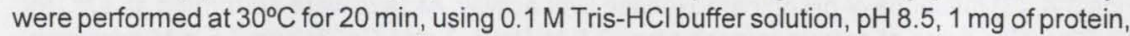
$0.5 \mathrm{M} \mathrm{NaCl}$ and $2 \mathrm{mM} \mathrm{CaCl}_{2}$. Each point is the mean of six assays.

Table I. Paraoxonase activity in cellular subfractions of pacu liver.

\begin{tabular}{lcrcrc}
\hline \multirow{2}{*}{ Fraction } & $\begin{array}{c}\text { Protein } \\
\left(\mathrm{mg}^{*}\right)\end{array}$ & \multicolumn{4}{c}{ Paraoxonase activity } \\
\cline { 3 - 6 } & & \multicolumn{1}{c}{$\begin{array}{c}\text { Units/mg protein } \\
\left(10^{4}\right)^{*}\end{array}$} & $\begin{array}{c}\text { Total amount } \\
(\text { mmoles/min) }\end{array}$ & $\begin{array}{c}\text { Yield } \\
(\%)\end{array}$ & $\begin{array}{c}\text { Purification factor } \\
\text { (fold) }\end{array}$ \\
\hline Homogenate & $608.7 \pm 32$ & $12.0 \pm 0.90$ & 0.73 & 100 & 1.00 \\
First supernatant & $467.9 \pm 19$ & $9.2 \pm 0.43$ & 0.43 & 59 & 0.77 \\
Nuclear pellet & $141.0 \pm 13$ & $20.6 \pm 0.58$ & 0.29 & 40 & 1.72 \\
Second supernatant & $295.2 \pm 16$ & $6.2 \pm 0.43$ & 0.18 & 25 & 0.52 \\
Microsomal fraction & $136.4 \pm 11$ & $11.6 \pm 0.72$ & 0.16 & 21 & 0.97 \\
\hline
\end{tabular}

*) Numbers refer to four experiments \pm S. E. M. Assays were performed at $30^{\circ} \mathrm{C}$ for $20 \mathrm{~min}$, using $0.1 \mathrm{M}$ Tris- $\mathrm{HCl}$ buffer solution, $\mathrm{pH} 8.5,0.5 \mathrm{M} \mathrm{NaCl}, 2 \mathrm{mM} \mathrm{CaCl} 2,1 \mathrm{mg}$ protein and 7.5 $\mathrm{mM}$ paraoxon.

\section{DISCUSSION}

Misleading information can result when physiopathologic responses are evaluated based on enzyme activity levels without proper adaptations of enzyme determinations. Enzymes may be characterized for their time course of reaction, proportionality of activity to enzyme concentration, effects of $\mathrm{pH}$ and ionic strength, substrate optimum concentration and other reaction parameters. Regrettably, too often it is seen that many laboratories simply reproduce procedures established elsewhere, for diverse organisms.

The results shown in figures 1 to 5 indicate that pacu liver paraoxonase activity was kinetically assayed using $1 \mathrm{mg}$ of liver homogenate proteins in a Tris- $\mathrm{HCl}$ buffer, $\mathrm{pH} 8.5$, containing $0.5 \mathrm{M} \mathrm{NaCl}$ and $2 \mathrm{mM} \mathrm{CaCl}_{2}$ for 20,40 or even $60 \mathrm{~min}$ of incubation. No significant deviation of the paraoxon hydrolysis from its initial velocities was verified under such conditions. 
It has been established that two allozymic forms of esterases account for the paraoxonase activity present in human serum (PLAYFER et al. 1976; SMOLEN et al. 1991) and that the simplest way to reach qualitative distinction between them is to assay human serum in the presence and absence of $1 \mathrm{M} \mathrm{NaCl}$ (ECKERSON et al. 1983). As it happens with others serum enzymatic proteins, fish serum paraoxonase might also be produced in liver cells and secreted into serum. Thus, it is possible to hypothesize that the $\mathrm{NaCl}$ activation of the liver activity, clearly demonstrated by the ratio between apparent $V_{\max }$ and $\mathrm{K}_{\mathrm{M}}$, could be an indication of the presence of the two paraoxonase phenotypes in this fish species.

Earlier results concerning human serum arylesterase inhibition by EDTA (ERDÖs et al. 1959) showed that high levels of inhibition are observed at EDTA concentrations higher than $0.01 \mathrm{mM}$ as a result of calcium chelation. Once paraoxonase has been classified as an arylesterase, the inhibition of the pacu liver paraoxonase activity caused by EDTA found here suggests that the enzyme molecule responsible for this activity in pacu liver could be, in fact, a paraoxonase protein.

Paraoxonase activity from trout (Salmo trutta) liver using less than $0.1 \mathrm{M}$ $\mathrm{NaCl}$ in the assays has been reported as being of $2.0 \mathrm{nmol} / \mathrm{g}$ tissue $/ \mathrm{min}$ (CHEMNITIUS et al. 1983). Calculating from our data, obtained in $1 / v \times 1 /[\mathrm{S}]$ plots, pacu liver showed activity levels higher than $100 \mathrm{nmoles} / \mathrm{g}$ tissue/min, even in assays without $\mathrm{NaCl}$. Based on this, it is reasonable to conjecture that each fish species has different liver abilities to hydrolyze organophosphate pesticides.

Paraoxonase activity appeared more related to particulate cellular subfractions in pacu liver than to soluble ones (Tab. I). This agrees with previous findings in rat liver (POND et al. 1995) and seems to support the assumption that serum paraoxonase should be originated in liver cells and secreted via cellular mechanisms involving membrane organelles. However, if one is interested in a high purification yield, our findings indicate that a preliminary step to make paraoxonase more soluble from liver homogenate should be carried out in order not to loose a significant amount of the enzyme in the pellets.

Until now, there has been no information on $\mathrm{K}_{\mathrm{M}}$ values of liver paraoxonase in any fish species. Determining $\mathrm{K}_{\mathrm{M}}$ for paraoxonase activities in fish tissues may be of importance to assess what would be the range of paraoxon concentration that could be most effectively inactivated by hydrolysis. It seems reasonable to consider that in vivo concentrations of paraoxon in fish exposed to lethal and sublethal doses of parathion is likely below the $\mathrm{K}_{\mathrm{M}}$ we observed for pacu liver paraoxonase activity. Thus, liver paraoxonase might not represent a true detoxicating step concerning organophosphate intoxication of pacu, for the enzyme would split paraoxon with half of its maximum velocity only at paraoxon concentrations higher than those already capable of affecting the cholinergic nerves of pacu.

ACKNOWLEDGEMENTS. The authors are grateful to the support provided by the Rio de Janeiro State Research Support Foundation (FAPERJ). 


\section{REFERENCES}

BURNS, K.A. 1976. Microsomal mixed function oxidases in an estuarine fish, Fundulus heteroclitus, and their induction as a result of environmental contamination. Comp. Biochem. Physiol. 53B: 443-446.

Chemnitius, J-M.; H. LosCH; K. LOSCH \& R. ZECH. 1983. Organophosphate detoxicating hydrolases in different vertebrate species. Comp. Biochem. Physiol., 76C: $85-93$.

Cunha Bastos, J.; V.L.F. Cunha Bastos; A. Rossini; H. Fortini \& M.V. CASTRO FARIA. 1992. Activation of parathion by liver of Hypostomus punctatus, a Brazilian benthic fish (Cascudo). Comp. Biochem. Physiol. 102C: 561-566.

CunHa Bastos, V.L.F.; J. CunHa Bastos; A. Rossini; M.V. Alves; P.S. CECCARELli \& J.A. FERRAZ DE LiMA. Paraoxon esterase activity in sera from Piaractus mesopotamicus Holmberg (Characidae) and Hypostomus punctatus Valenciennes (Siluridae). Revta bras. Zool. 15.

ECKERSON, H.W.; J. ROMSON; C. WYTE \& B.N. LA DU. 1983. The human serum paraoxonase polymorphism: identification of phenotypes by their response to salts. Amer. Jour. Hum. Genet. 35: 214-227.

ERDÖS, E.G.; C.R. DEBAY \& M.P. WESTERMAN. 1959. Activation and inhibition of the arylesterase of human serum. Nature 184: 430-431.

FARIA, H.C. \& A. BRASIL. 1959. Adaptação foto-colorimétrica do método de Greenberg, para dosagem das proteínas do soro. O Hospital 55: 597-601.

GAINES, T.; W.J. HAYES \& R.E. LINDER. 1966. Liver metabolism of anticholinesterase compounds in rats: Relation to toxicity. Nature 209: 88-89.

GELDMACHER-VON MALLINCKRODT, M. \& T.L. DieBgEN. 1988. The human serum paraoxonase - polymorphism and specificity. Toxicol. Environ. Chem. 18: 79-196.

Grave, K.; M. Engelstad \& N.E Solly. 1991a. Utilization of dichlorvos and trichlorfon in salmonid farming in Norway during 1981-1988. 1991a. Acta Vet. Scand. 32: 1-7.

Grave, K.; M. Engelstad; N.E. Soli \& E.L. Toverud. 1991b. Clinical use of dichlorvos (Nuvan) and trichlorfon (Neguvon) in the treatment of salmon louse, Lepeophtheirus salmonis. compliance with the recommended treatment procedures. Acta Vet. Scand. 32: 9-14.

GREENBERG, D.M. 1929. The colorimetric determination of the serum proteins. Jour. Biol. Chem. 82: 545-550.

HINTON, D.E.; J.E. KLAUNIG \& M.M. LIPSKY. 1978. PCB-induced alterations in teleost liver: A model for environmental disease in fish. Mar. Fish Rev. 40: 47-50.

HINTON, D.E.; J.A. HAMPTON \& R.C. LANTZ. 1985. Morphometric analysis of liver in rainbow trout quantitatively defining an organ of xenobiotic metabolism. Mar. Environ. Res. 17: 238-239.

LI, W.F.; C.E. Furlong \& L.G. CostA. 1995. Paraoxonase protects against chlorpyrifos toxicity in mice. Toxicol. letters 76: 219-226.

NEAL, R.A. 1967. Studies on the metabolism of diethyl-4-nitrophenyl phosphorothionate (parathion) in vitro. Biochem. Jour. 108: 183-191.

NEAL, R.A. \& K.P. DuBoIs. 1965. Studies on the mechanism of detoxification of 
cholinergic phosphorothioates. Jour. Pharmacol. Exp. Therapeut. 148 (2): 185-192.

NowAK, B. 1996. Relationship between endosulfan residue level and ultrastructural changes in the liver of Catfish, Tandanus tandanus. Arch. Environ. Contam. Toxicol. 30: 195-202.

Pedersen, M.G.; W.K. Hershberger; P.K. Zachariah \& M.R. Juchau. 1976. Hepatic biotransformation of environmental xenobiotics in six strains of rainbow trout (Salmo gairdneri). Jour. Fish. Res. Board Can. 33: 666-675.

PLA, A. \& M.K. JOHnSON. 1989. Degradation by rat tissues in vitro of organophosphorus esters which inhibit cholinesterase. Biochem. Pharmacol. 38: 15271533.

PlAyFER, J.R.; L.C. EZE; M.F. BULLEN \& D.A.P. EVANS. 1976. Genetic polymorphism and interethnic variability of plasma paraoxonase activity. Jour. Med. Genet. 13: 337-342.

POND, A.L.; H.W. ChAMBERs \& J.E. ChAMBERS. 1995. Organophosphate detoxication potential of various rat tissues via A-esterase and aliesterase activities. Toxicol. Letters 78: 245-252.

SMOlen, A.; H.W. EcKerson; K.N. Gan; N. Hailat \& B.N. La Du. 1991. Characteristics of the genetically determined allozymic forms of human serum paraoxonase/arylesterase. Drug Metab. Dispos. 19: 107-112.

SulTATOS, L.G.; L.D. MinOR \& S.D. MURPHY. 1985. Metabolic activation of phosphorothioate pesticides: role of the liver. Jour. Pharmacol. Exp. Therapeut. 232: 624-628.

Recebido em 24.III.1997; aceito em 03.VIII.1998. 